УДК 531.7

V. V. Novikov, $\mathrm{PhD}$

Odessa State Academy of Technical Regulation and Quality

\title{
METHOD OF THE PRECISION DILATOMETRIC STUDIES OF METALLIC GLASSES
}

Results are given of detailed studies of the temperature dependence of relative lengthening in a number of $\mathrm{Fe}$-, $\mathrm{Ni}$-, and Co-based metallic glasses $(\mathrm{MG})$, applying an improved dilatometric method.

Keywords: temperature dependence of relative lengthening, metallic glasses, dilatometric method.

\section{Introduction}

Today great attention is paid to the study of isothermal annealing in the range of temperatures which are some hundreds degrees lower than the temperature of crystallization $(T c)^{\prime}$ and to the lateration of physical properties of the as-quenched metallic glasses (MG) [1 to 3]. One of the reasons which arouse the interest in the processes of lowtemperature structural relaxation is determined by the necessity of searching ways of increasing the stability of amorphous metallic alloys. Another, not less important reason for the increased interest in such research is the necessity to establish the physical essence of structural relaxation and in working out a model mechanism, which would allow to describe correctly the experimentally observed processes caused by isothermal annealing of as-quenched MG.

It was established as a result of a great number of experiments that low-temperature structural relaxation stabilizes the physical properties of MG relative to the state of the as-quenched samples (the alloys turned into a more stable amorphous state). Alteration of most of the physical properties of MG in the process of structural relaxation amounts to about $10 \%$ of the whole variation of the properties during the crystallization of the alloy. Thus, if the general reduction of the volume during the crystallization of $\mathrm{MG}$ amounts to $\Delta V / V \approx 2 \%$, then $\Delta V / V$ as a result of the structural relaxation of the asquenched samples is $\approx 0.2 \%$. According to the data we found in the literature, the volume of MG in the process of structural relaxation always decreases irreversibly (the density of the alloy always increases).

Irreversible contraction of the volume of the asquenched MG during low-temperature isothermal annealing is in most cases linked to the excess free volume going out of the sample, that is introduced into the ribbon in the process of freezing from the liquid state [6]. Irreversible stabilization of the structure is thus the consequence of the annihilation of defects present in the as-quenched MG [1,4].

Recently new experimental peculiarities of the physical properties at low-temperature structural relaxation of MG have been revealed. In particular, the results of investigations of reversible modifications in the thermal heat capacity of the amorphous alloy $P d_{48} N i_{32} P_{20}$ after preliminary isothermal annealing at $T_{a}=380 \mathrm{~K}$ are given in [1].
Obviously, the new aspects of structural relaxation do not fit fully into the frame of the model of free volume and require a detailed experimental study.

In the present work the metallic glasses $\mathrm{Fe}_{40} \mathrm{Ni}_{40} \mathrm{P}_{14} \mathrm{~B}_{6}, \mathrm{Co}_{55} \mathrm{Ni}_{14} \mathrm{Fe}_{5} \mathrm{Si}_{16} \mathrm{~B}_{10}, \mathrm{Co}_{77} \mathrm{Cr}_{7} \mathrm{Fe}_{4} \mathrm{Si}_{8} \mathrm{~B}_{4}$ obtained as ribbons by the method of centrifugal spinning have been studied.

\section{Experimental Methods}

Application of the traditional dilatometric methods to study the temperature dependence of lengthening requires to apply tensile loads to the sample (thin ribbon) and, since amorphous metallic alloys display at high temperatures noticeable fluidity even in case of a few grams loading per $\mathrm{mm}^{2}$ [5], the inaccuracy of the definition $(\Delta l / l)(T)$ due to creeping can be considerable [6].

To carry out precision dilatometric investigations on $\mathrm{MG}$, a special highly sensitive differential method was used, the working principle of which was described in $[7,8]$.

The main distinguishing feature of the suggested method is that the sample (a small piece of ribbon $50 \mathrm{~mm}$ long and $43 \mathrm{~mm}$ wide) is fixed at its extremities to a standard sample made of a material with a known temperature coefficient of expansion, the central part of the ribbon having a small flexure $(0.1$ to $0.3 \mathrm{~mm})$ relative to the flat surface of the standard sample. $(\Delta l / l)(T)$ of the ribbon can be calculated by the temperature dependence of the value of the ribbon sag relative to the standard sample. $(\Delta l / l)$ is calculated from the following formulae:

$$
\frac{\Delta l}{l}(T)=\left(\frac{\Delta l}{l}(T)\right)^{\prime}+\left(\frac{\Delta l}{l}(T)\right)_{S},
$$

where $\left(\frac{\Delta l}{l}(T)\right)_{S}$ is the lengthening of the standard sample, $\left(\frac{\Delta l}{l}(T)\right)^{\prime}$ the lengthening of the ribbon relative to the standard sample,

$$
\left(\frac{\Delta l}{l}(T)\right)=\frac{8\left(\lambda^{2}(T)-\lambda_{0}^{2}\right)}{3 l_{0}^{2}},
$$

$l_{0}$ the distance between the points where the ribbon is fixed to the standard sample at the initial 
temperature, $\lambda_{0}$ the initial value of the ribbon sag relative to the standard sample, $\lambda(T)$ the value of the ribbon sag at the temperature $T$.

It follows from (2) that the dependence of the value $(\Delta l / l)(T)$ sought for upon the measured value $\lambda(T)$ is quadratic; this determines the high sensitivity of this method. If measuring the sag with a comparator has a tolerance of $0.001 \mathrm{~mm}$ and one chooses $\lambda_{0}$ to be $0.1 \mathrm{~mm}$, the error in measuring $\Delta l / l$ should be $\approx 10^{-7}$.

In fact, in a metrological check the error on $(\Delta l / l)(T)$ with real values of $\lambda_{0} l_{0}$ and $\lambda(T)$ resulted to be about $3 \cdot 10^{-7}$ i.e. lying within the sensitivity limits of the method. A detailed deduction of (1), (2), and an error analysis are given in [3].

We stress that the described dilatometric method is differential, therefore, it allows to measure the temperature coefficient of expansion with high precision. In addition, the obvious advantage of the above-described method is that during the measurement the MG sample (ribbon) is in a free, practically unloaded state. This increases considerably the reliability of our dilatometric analysis of MG, especially at higher temperatures, where creep is noticeable in the samples.

\section{Results and Discussion}

We begin the account of the results of the investigation with the most thorough by studied MG $\mathrm{Fe}_{40} \mathrm{Ni}_{40} P_{14} B_{6}$. The temperature dependence of the relative lengthening of this amorphous alloy, obtained by applying the above-described method of $(\Delta l / l)$ measurement, was published in [9]. It was shown that the volume modification of the MG $\mathrm{Fe}_{40} \mathrm{Ni}_{40} P_{14} B_{6}$ during crystallization depends on the heating rate of the ribbon below the crystallization temperature. According to the data in [9], the volume modification during the transition of the amorphous ribbon to the crystalline state at $T=400{ }^{\circ} \mathrm{C}$ amounts to $1.45 \%$ for a ribbon heated at a rate of $0.17 \mathrm{~K} / \mathrm{s}$ and $1.86 \%$ for a ribbon heated at a rate of $0.01 \mathrm{~K} / \mathrm{s}$. The dependence of the volume modification during crystallization on the heating rate of the MG is determined by processes connected with the redistribution of the concentrations of the crystalline phases which are bound to be much more intensive at low heating rates.

Let us make a more detailed analysis of the temperature dependence of the lengthening of the MG $\mathrm{Fe}_{40} \mathrm{Ni}_{40} P_{14} B_{6}$, (Fig. 1) taking into account the experimental data which show the influence of preliminary isothermal annealing in the range of precrystallization temperatures on the $(\Delta l / l)(T)$ variation. While heating the mentioned amorphous alloy till $T \approx 200{ }^{\circ} \mathrm{C}$, the $(\Delta l / l)(T)$ dependence is represented by a straight line that shows the absence of noticeable crystallization processes in this temperature range.

The temperature coefficient of linear expansion of the amorphous alloy is $\alpha_{a}=(1.39 \pm 0.05) \cdot 10^{-5} \mathrm{~K}^{-1}$.
During further heating the influence of structural relaxation and crystallization processes (which diminish the MG volume) on the type of $(\Delta l / l)(T)$ dependence becomes noticeable (solid line in Fig. 1). There appears an ever increasing deviation of the $(\Delta l / l)$ curve from the dash-dotted straight line corresponding to the expansion coefficient of the initial amorphous alloy $\alpha_{a}$. In the temperature range of most intensive crystallization $\left(\approx 400{ }^{\circ} \mathrm{C}\right)$, the $(\Delta l / l)(T)$ curve has a most explicit maximum, after which the volume sharply decreases indicating crystallization. Most interesting is the fact that the maximum of the $(\Delta l / l)(T)$ curve comes close to the extrapolated straight $(\Delta l / l)(T)$ line corresponding to the temperature coefficient of expansion of the amorphous alloy $\alpha_{a}$ (dash-dotted line in Fig. 1). The volume of the sample in the range of the maximum $(\Delta l / l)(T)$ approaches the volume of the initial amorphous alloy at $T \approx 400{ }^{\circ} \mathrm{C}$.

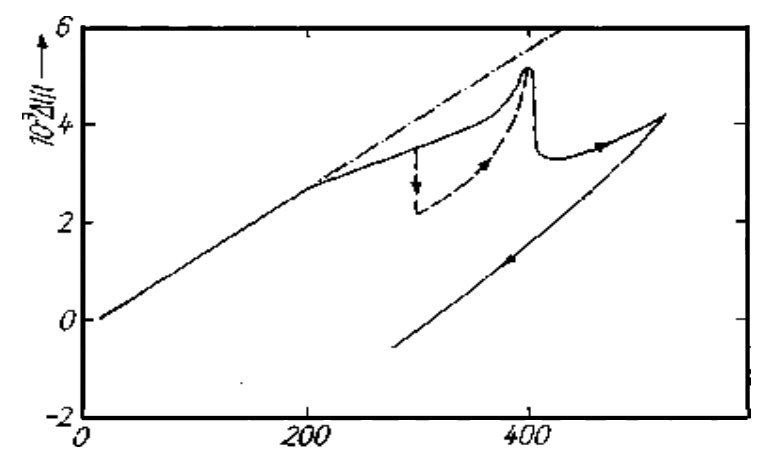

Figure 1 - The temperature dependence of relative lengthening in the MG $\mathrm{Fe}_{40} \mathrm{Ni}_{40} P_{14} B_{6}$ (----), expansion coefficient of the initial amorphous alloy (-- ---) and MG lengthening after preliminary annealing (- - -)

The first question which arises when analysing $(\Delta l / l)(T)$ is: why should the sample volume increase in the range of higher temperatures, where the crystallization of MG goes on intensively, approaching the amorphous state volume of the alloy at $T \approx 400{ }^{\circ} \mathrm{C}$.

From our point of view, in order to explain our experimental results one must use the main points of the model of crystallization with "frozen-in" centers proposed by the authors of [10], especially as the centers of crystallization in as-quenched amorphous alloys are really observed with the help of electronmicroscopic methods $[1,4,10]$.

In conclusion we give one more experimental result which speaks in favour of the theoretical model proposed by us. Fig. 2 shows the volume changes during the process of isothermal annealing of the MG $F_{84} B_{16}$. It follows from Fig. 2 that, contrary to the existing ideas about an inevitable reduction in the volume of the amorphous alloy during structural relaxation, annealing of the MG 
$\mathrm{Fe}_{84} \mathrm{~B}_{16}$ may lead both to a decrease and an increase of the sample volume; this lies obviously outside the scope of the excess free volume model.

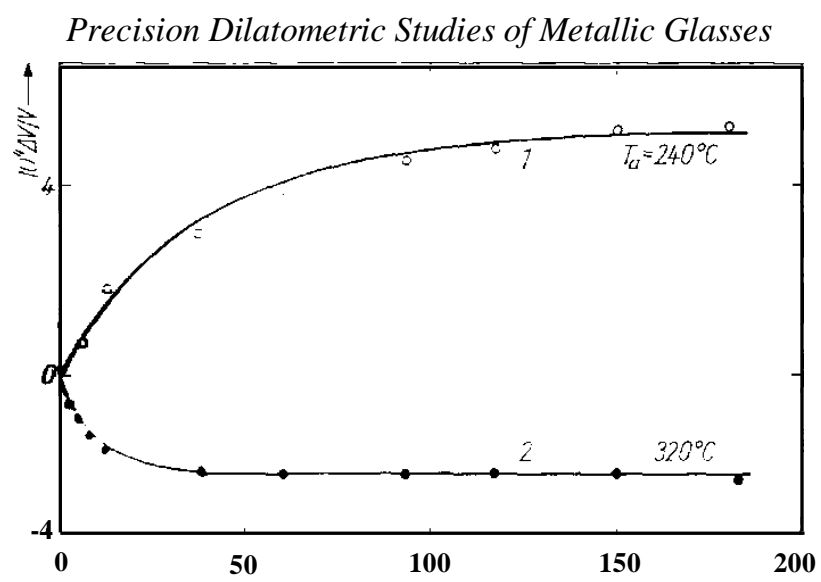

Figure 2 - Relative volume modification of the MG $\mathrm{Fe}_{84} B_{16}$ in the process of annealing at $T_{a}=240$ and 320 ? .

Thus after annealing at $T_{a}=240{ }^{\circ} \mathrm{C}$ during $3 \mathrm{~h}$. the volume of the MG $\mathrm{Fe}_{84} \mathrm{~B}_{16}$ increased by $0.05 \%$, while annealing for the same duration at $T_{a}=320^{\circ} \mathrm{C}$ leads to a volume decrease by $0.02 \%$.

The state of the MG $F_{84} B_{16}$ in the range $T \approx 240{ }^{\circ} \mathrm{C}$, which corresponds to the greater molar volume (in comparison with the initial sample) is to be considered thermodynamically more advantageous. It is characteristic that at room temperature the microhardness of the analysed MG after annealing at $T_{a}=240{ }^{\circ} \mathrm{C}$ during $3 \mathrm{~h}$ is lower than in the initial sample by $5 \%$ and after annealing at $T_{a}=320^{\circ} \mathrm{C}$ is higher than in the initial sample by $2 \%$.

4. Conclusions

1. A highly sensitive differential method has been devised for studying the relative changes in the length of thin MG ribbons during heating and isothermal annealing within a broad temperature range.

2. As a result of the precision dilatometric studies, it has been established that structural relaxation of the $\mathrm{MG} F e_{84} B_{16}$ determined by isothermal annealing at $T_{a}=240{ }^{\circ} \mathrm{C}$ is followed by a decrease of the alloy density. That contradicts the statement of the excess free volume model about an inevitable increase of the density of amorphous alloys in the process of structural relaxation.

\section{References}

1. K. Sudzuky, X. Fusimory and K. Hasimoto. Amorfniye metallic. Metallurgizdat. Moscow 1987.

2. T. Komatsu, K. MATUSITA, and R. YOKOTA, J. non-crystall. Solids 85, 3.58 (1986).

3. L. Leonardson, Proc. 5-th Internat. Conf., Rapidly Quenched Metals, Vol. 1, Amsterdam 1985 (p. 1354). (1984).

4. M. Popescu, Thin Solid Films 121, 317

5. J. C. Gibeling and W. D. Nix, Scripta metall. 12, 919 (1978).

6. B. Kantor, Bistrozakalyonniye metalli, Izd. Mir, Moscow 1983.

7. V. K. Novikov and E. I. Harcov, Fiz. khim. Stekla 13, 764 (1987).

8. P. Maslov, and V. N. Novikov, Problemy p.A. A. Dvorski, V. rochnost. 6, 118 (1987).

9. V. N. Novikov and E. I. Harcov, Fizika Metallov i Metallovedenie 54, 1210 (1982).

10. Y. Hirotsu and R. Akoda, Japan. J. appl. Phys. 23, 479 (1984).

\section{Надійшла до редакиії 17.05.2013}

Рецензент: д.т.н., професор Коломієць Л.В., Одеська державна академія технічного регулювання та якості, м. Одеса.

\section{В. В. Новиков, к.Т.н.}

\section{МЕТОД ПРЕЦЕЗИОННОГО ДИЛАТОМЕТРИЧЕСКОГО ИЗУЧЕНИЯ МЕТАЛЛИЧЕСКИХ СТЕКОЛ}

Приведен обзор оригинальных экспериментальных результатов, полученных при детальном изучении температурных зависимостей относительного удлинения ряда металлических стекол на основе Fe, Ni и Cо, используя специальную дилатометрическую методику.

Ключевые слова: температурная зависимость относительного удлинения, металлические стекла, дилатометрическая методика.

\section{В. В. Новіков, К.т.н.}

\section{МЕТОД ПРЕЦЕЗІЙНОГО ДІЛАТОМЕТРИЧНОГО ВИВЧЕННЯ МЕТАЛЕВИХ СТЕКОЛ}

Приведений огляд оригінальних експериментальних результатів, отриманих при детальному вивченні температурних залежностей відносного подовження ряду металевих стекол на основі Fе, Ni i Co, використовуючи спеціальну ділатометричну методику.

Ключові слова: температурна залежність відносного подовження, металеві стекла, ділатометрична методика. 